\title{
Measures of the Winter Package EC and Biogas Power Plants in Croatia
}

\author{
Milan Ivanović \\ Panon - Think Tank for Strategic Studies Osijek \\ Vijenac Ivana Meštrovića 19, Osijek, Croatia \\ milanivanovi4@gmail.com

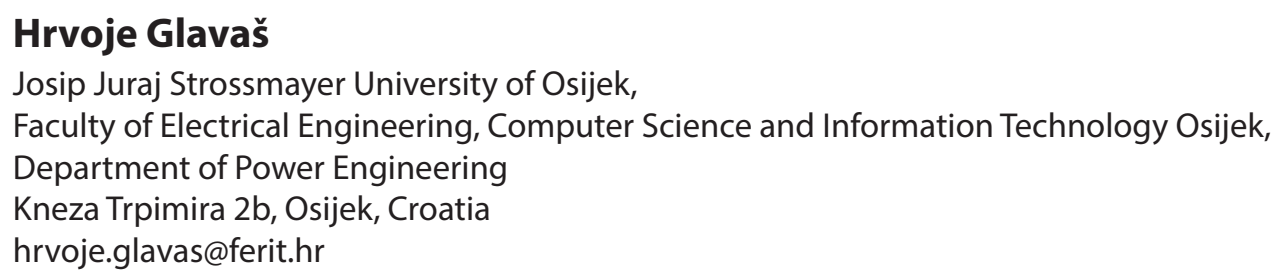

\begin{abstract}
This paper is based on the revised EU energy policy measures proposed by the European Commission in the so-called Winter Package, with special reference to biogas plants in the Republic of Croatia. The paper gives an overview of biogas power plants built in Croatia, a technological framework for their functioning, the installed power and their contribution to power supply in the country. The paper points to the importance of electricity and heat production from biogas power plants and the possibilities of a framework for the future development of these power plants in the Republic of Croatia.
\end{abstract}

Keywords - biogas, biogas power plants, electricity prices, electricity generation, winter package EC

\section{INTRODUCTION}

On 30 November 2016, the European Commission presented a proposal for measures to establish a new energy policy (the so-called Winter Package) with the aim of preserving competitiveness of the EU on the way to clean energy. More than 40 measures were introduced, which serve the following three fundamental goals:

a. priority for energy efficiency in buildings, energy efficiency in the industry and the transport sector,

b. achieving global leadership in the field of energy from renewable energy sources, and

c. establishing a common EU energy market and ensuring appropriate solutions for energy consumers.

New goals have been set for the purpose of reducing greenhouse gas emissions, and increasing energy efficiency and the overall share of renewable energy sources in total energy consumption. The proposed measures present a continuous reform of the EU energy sector in the field of electricity generation, energy efficiency, and efficient energy use in buildings, transport and industry. In terms of renewable energy sources (RES), it is very important that the abolition of the obligation of first purchase is proposed. The Winter Package of the EC has therefore started a redesign of the energy market and energy management, and for the first time it has introduced a unique climate and energy policy. The European Commission has outlined the proposed measures and introduced new views on prices and energy costs and the need to accelerate innovation in the area of clean energy, [1]. This paper focuses on the importance of biogas power plants and considers a possible scope of their operation in the new conditions expected in the coming period.

\section{BIOGAS PRODUCTION IN THE EU}

Significant construction of biogas power plants and biogas technology development in the EU began in the 1990s, and a very serious development policy in this sector has begun by adopting a number of EU strategic documents on energy development and ecological policies, [2-3]. Thus, the Waste Landfill Directive (1999/31/EC) has contributed to the EU's goals of biogas production; i.e. Member States had to reduce the amount of biodegradable waste disposed of at landfills. Directive 2008/98/EC on waste encouraged recovery and reuse of waste, and the Renewable Energy Directive (2009/28/EC) contributed to the promotion 
of the use of energy from renewable sources; the target of a $20 \%$ share of energy from RES in final energy consumption in 2020 is also defined, [4-6].

Within the framework of national action plans for renewable energy, most EU Member States have developed biogas production programs based on preferential purchase prices (feed-in tariffs), green certificates or incentives for the use of energy crops. The promotion of feed-in tariffs differs in EU countries depending on: (1) the substrate used, (2) the size of the plant, (3) the use of heat energy, and (4) transportation of raw materials. These measures have yielded results and the production and use of biogas has increased significantly in the EU; Fig. 1.

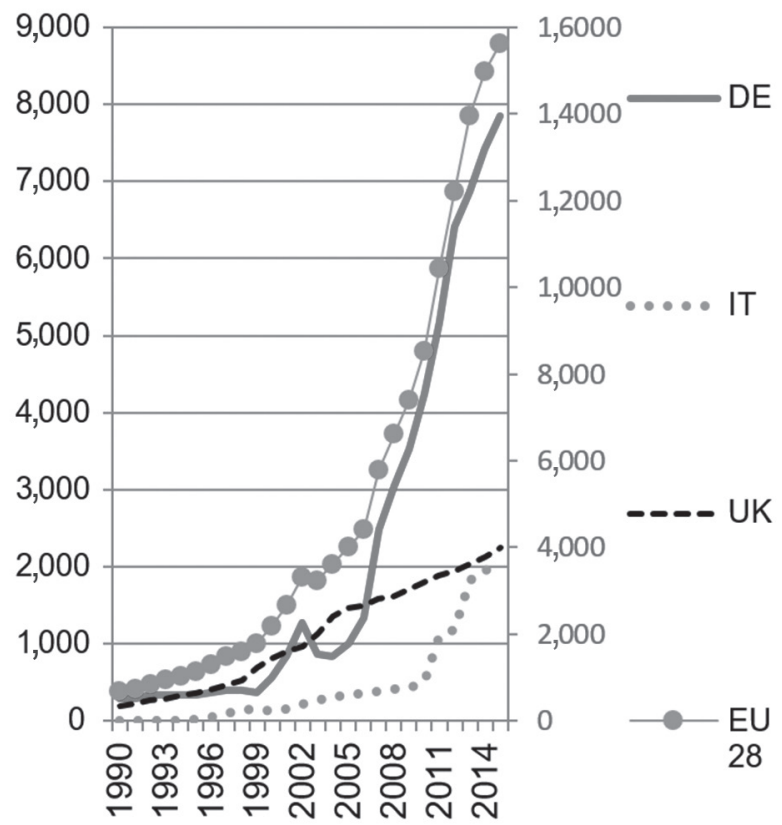

Fig. 1. Primary biogas production in EU-28; $10^{6}$ toe, [7]

Biogas production has increased from 665 million tons of oil equivalent (toe) in 1990 to 15.6 billion tons in 2015. Three countries are the largest biogas producers in the EU; i.e. Germany, Great Britain and Italy, with $50 \%, 14 \%$ and $12 \%$ of total EU production, respectively. In 2010,52\% of biogas was produced from agricultural substrates in the EU, 36\% from waste dumps (dump biogas) and $12 \%$ from wastewater treatment. The United Kingdom is the largest wastewater biogas producer in the EU, [8].

\section{BIOGAS POWER PLANTS IN THE REPUBLIC OF CROATIA}

Conditions for the cost-effective use of RES and cogeneration in Croatia exist since 2007. The incentive system and redemption prices from the feed-in tariff system for electricity production from RES and cogeneration made it possible for investments to be viable. Apart from energy production for one's own consumption, surplus electricity produced is also delivered to the public network, which is in line with the strategic objective of the energy policy of the Republic of Croatia; i.e. $35 \%$ of RES in electricity generation by the year 2020, [9]. In the last nine years, 26 biogas power plants (BPPs) of total electric power $30.4 \mathrm{MWel}$ were constructed and put into operation, as well as two more power plants - one landfill power plant and one wastewater treatment plant with the total power of 5.5 MWel; Fig. 2 and Fig. 3. As of 31 December 2016, the Croatian Energy Market Operator (HROTE) has signed 25 contracts for projects for the construction of new biogas plants of total power 25,785 kW, [10].

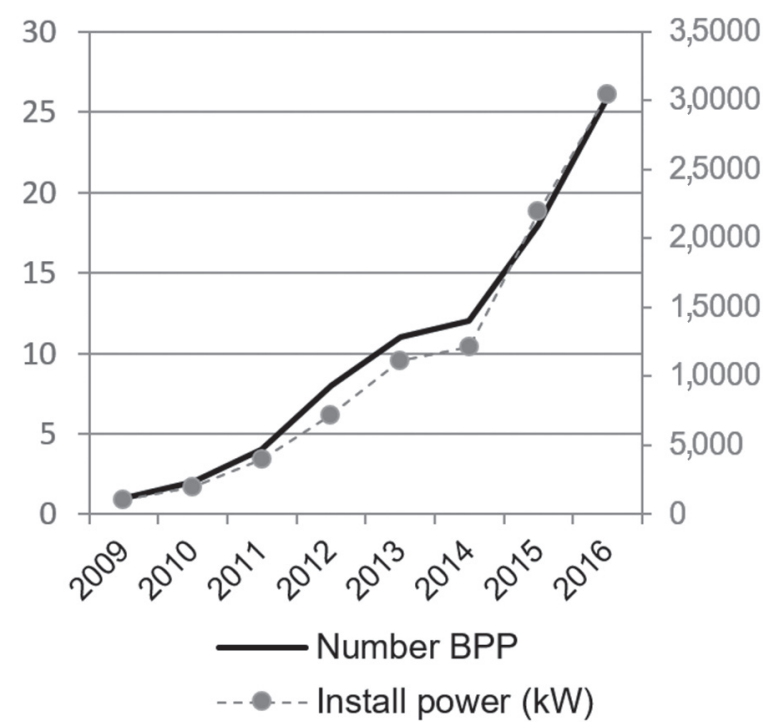

Fig. 2. Number and installed electric power of biogas power plants (BPP) in the Republic of Croatia [10-11]

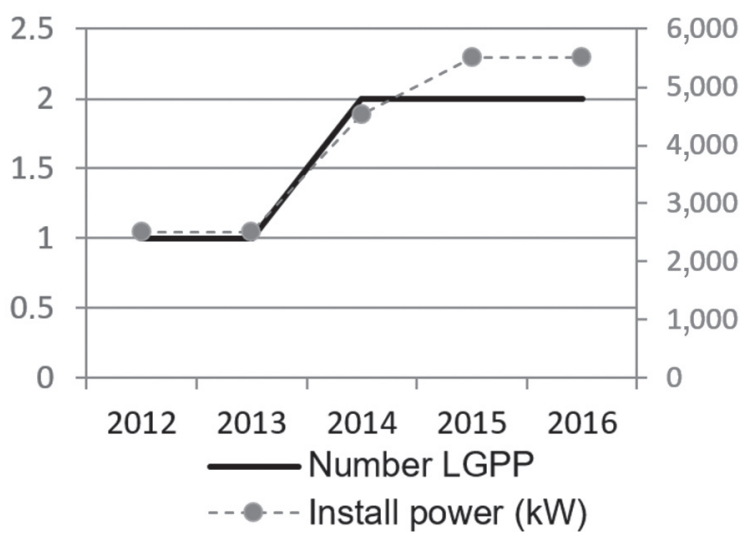

Fig. 3. The number and installed electric power of the power plant at the landfill gas (LGPP) in the Republic of Croatia [10-11 ]

Biogas production in Croatia in international relations is shown in Figure 4. For the purpose of comparison, some of our neighboring countries have been selected; Italy (1.9 billion toe) and Austria (300 million toe) are far above the comparison level with the Republic of 
Croatia, and there is no registered biogas production in Bosnia and Herzegovina and Montenegro. Croatia has biogas production at the level of Slovenia biogas production, five times greater than Serbia, but almost half of production in Hungary, [10-11].

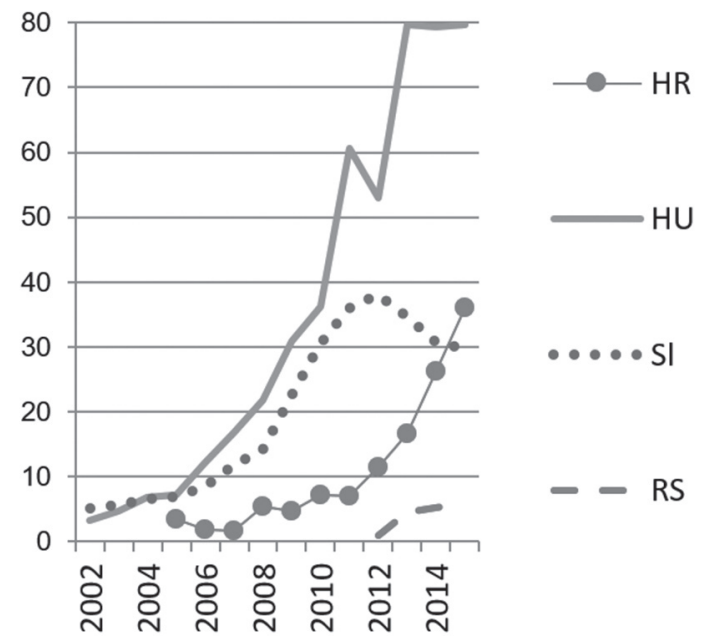

Fig. 4. Biogas production in Croatia, Hungary, Slovenia and Serbia ( $\bullet 103$ toe) [7]

In 2016, Croatian RES power plants produced 1,266 GWh of electricity. 28 biogas power plants with the total power of $35.9 \mathrm{MWel}$ generated and delivered 210 GWh of electricity to the Croatian power system, which represents $12 \%$ of RES in electricity produced in Croatia.

\subsection{RES POWER PLANTS IN THE REPUBLIC OF CROATIA}

In the early 2000s, the Republic of Croatia adopted several documents that adapted Croatian energy policy to the EU framework; a system of feed-in tariffs for stimulating electricity production from RES and high efficiency cogeneration was built and has been used since 1 July 2007, [12-13]. Since then, activities have started on the construction of RES power plants in Croatia. By the end of 2016, 1,294 RES power plants were built and commissioned with the total power of 640 MWel; Table 1.

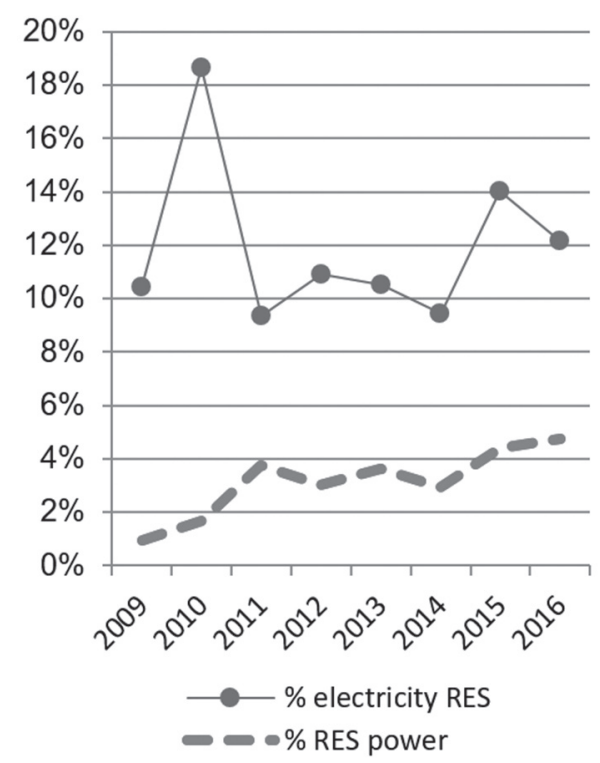

Fig. 5. The share of biogas plants in overall installed electric power and the share of energy production from biogas plants in the total capacity of RES power plants in the Republic of Croatia [10-11 ]

In RES electricity production in the Republic of Croatia, the largest share refers to wind power plants (59\%) and cogeneration plants (14\%). Small hydroelectric power plants, photovoltaic power plants, and biogas and biomass power plants are represented by $27 \%$ in the total RES electricity generation in the Republic of Croatia. Figure 6 shows the dynamics of their electricity production in 2016 by months.

In particular, reference should be made to the average installed power of RES plants in the Republic of Croatia; wind power plants and cogeneration plants have the largest installed power per single power plant in 2016; and the smallest installed power is connected with photovoltaic and hydroelectric power plants; Table 1 and Fig. 7.

Table 1. RES power plants HROTE has concluded an electricity purchase contract with under the tariff system and that are in the incentive system - Power Plants Status 31 December 2016

\begin{tabular}{|c|c|c|c|c|c|c|}
\hline No & RES Power Plants & No of plants & $\begin{array}{l}\text { Total rated power } \\
(\mathbf{k W})\end{array}$ & $\begin{array}{c}\text { Average power } \\
\text { (kW) }\end{array}$ & Share in total & $\begin{array}{c}\text { Share in total RES } \\
\text { power }\end{array}$ \\
\hline 1 & Solar power plants & 1,219 & 49,479 & 41 & $94.2 \%$ & $7.7 \%$ \\
\hline 2 & Hydropower plants & 11 & 3,885 & 353 & $0.9 \%$ & $0.6 \%$ \\
\hline 3 & Biomass power plants & 12 & 25,955 & 2,163 & $0.9 \%$ & $4.1 \%$ \\
\hline 4 & Biogas power plants & 26 & 30,435 & 1,171 & $2.0 \%$ & $4.8 \%$ \\
\hline 5 & Landfill power plants & 2 & 5,500 & 2,750 & $0.2 \%$ & $0.9 \%$ \\
\hline 6 & Wind power plants & 18 & 412,000 & 22,889 & $1.4 \%$ & $64.3 \%$ \\
\hline 7 & Cogeneration plants & 6 & 113,293 & 18,882 & $0.5 \%$ & $17.7 \%$ \\
\hline 8 & Total RES power Plants & 1,294 & 640,547 & 495 & $100.0 \%$ & $100.0 \%$ \\
\hline
\end{tabular}




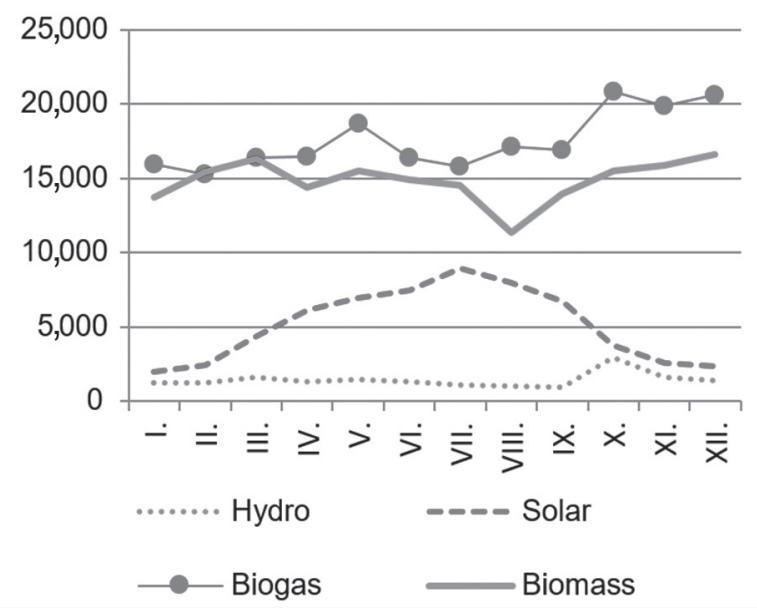

Fig. 6. Monthly electric power generation from hydro power plants, photovoltaic power plants, biomass and biogas in Croatia (MWh), [10-11 ]

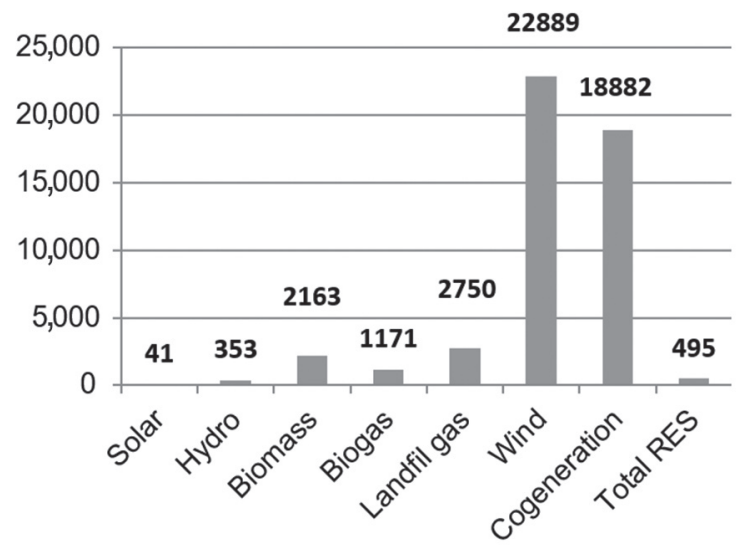

Fig. 7. Average installed electric power per RES power plant in Croatia, by RES type (kWh), [10-11 ]

\subsection{BIOGAS POWER PLANTS UNDER NEW CONDITIONS}

In the new business conditions with an emphasis on market criteria and competitive prices, as expected, biogas power plants in Croatia will have to adapt and operate within the EU framework. There are more reasons for optimism in these new frameworks. First of all, biogas power plants do not have a mere function of producing just electricity (like solar or wind power plants). Their mission is also related to management of livestock manure, wastewater and biodegradable municipal waste [13]. That ecological dimension has its own price that can contribute to optimism. Likewise, heat production has a quite specific economic potential as well as the residue of the production process, i.e. digestate, which represent new contributions to optimism for the future [14]. Biogas use in local public transport and communal transport should be used; some Scandinavian countries have been using biogas for years. In transition countries, where demographic problems and emigration processes of the working-age population are stressed, both direct employment and indirect economic use for the farmers-subcontractors should be taken into account. In these frameworks, local promoters of biomass production projects should be organized into a kind of consortium and in collaboration with professional and scientific teams, they should set up a phase of business development under new conditions.

\section{CONCLUSION}

In our biogas power plant analysis, the established system of feed-in tariffs and the incentive system for the construction of local renewable energy facilities in the Republic of Croatia give good results in the analyzed period:

a. In the period from 2009 to 2016,28 biogas power plants were constructed in the Republic of Croatia with the total power output of $35.9 \mathrm{MW}$.

b. Over this period, these biogas power plants produced and delivered to the Croatian electric power system an average of 10 percent of electricity produced in RES plants. In 2016, this production was $210 \mathrm{GWh}$.

c. In this way, the Republic of Croatia has achieved a new developmental step towards biogas production and ecological management of manure compared to several neighboring countries.

d. Significant part of design, construction and commissioning of these biogas power plants is done by national experts who have mastered this technology.

e. In addition to ecological and energy contribution, building a biomass power plant represents a great success when it comes to raising the technical level of production and business in the Republic of Croatia, but we should not neglect contribution (direct or indirect) to employment of the local population either.

Measures from the European Commission's Winter Package bring new criteria that could have a significant impact on the production of electricity from biogas power plants, and hence on the conditions of their business survival. It is therefore necessary for these producers to become interested and professionally associated in some kind of consortium that will organize the study of business and development opportunities under new market conditions.

\section{REFERENCES:}

[1] M. Dukan, 10 main messages from the European Commission's Winter Package, https://www. starfishenergy.org/single-post/ Zimski-paketWinter-Package/ Zimski-paket-Winter-Package (accessed: 2017) 
[2] M. Ivanović, Energy consumption, structure and development in European transition countries, IJECES - International Journal of Electrical and Computer Engineering Systems, Vol. 3, No. 2, 2012, pp. 7-16.

[3] M. Ivanović, European Trends of Renewable Energy Sources, Conference "Renewable Energy Sources in the Republic of Croatia", Proceedings, Zagreb, Croatian Chamber of Economy, 2007, pp. 237-247.

[4] Directive 1999/31/EC of 26 April 1999 on the landfill of waste

[5] Directive 2008/98/EC of 19 November 2008 on waste

[6] Directive 2009/28/EC of 23 April 2009 on the promotion of the use of energy from renewable sources

[7] Eurostat: http://ec.europa.eu/eurostat/data/ database, (accessed: 2017)

[8] Ž. Fištrek, Biogas market development in the European Union and potentials in Croatia; http:// www.biogasin.org/ files/pdf/hr_interaktivni/ 2_ Razvoj trzista bioplina u EU i potencijali u RH.pdf (accessed: 2017)
[9] Energy Development Strategy of the Republic of Croatia, Official Gazette 130/09

[10] HROTE - Annual Report on the System for the Promotion of Electricity from Renewable Energy Sources and Cogeneration in the Republic of Croatia for 2013; 2014; 2015; 2016.

[11] ElHP - Energy in Croatia 2009-2015, Ministry of Economy, Entrepreneurship and Crafts of the Republic of Croatia, Zagreb, 2015

[12] M. Ivanović, H. Glavaš, Green Electricity Production in EU-28, Croatia, Germany, Hungary and Serbia, 32nd International Conference Science in Practice, Proceedings, Faculty of Electrical Engineering Osijek, 2014

[13] M. Ivanović, H. Glavaš, D. Špiranović-Kanižaj, Energy Efficiency and Renewable Energy Sources in the Slavonia Region, SIP Proceedings, Pecs, 2012, pp. $63-70$.

[14] D. Jovičić, D. Kralik, M. Ivanović, M. Vukšić, J. Mirjanić, J. Dundović, Proizvodnja bioplina iz leguminoza, Europski poslovni forum o obnovljivim izvorima energije: knjiga sažetaka, HGK, Zagreb, 2010, pp. 23-25. 